\title{
Forage yield and quality potential of winter cereal-vetch mixtures under rainfed conditions
}

\author{
M. Ansar ${ }^{1 *}$, Z. I. Ahmed ${ }^{1}$, M. A. Malik ${ }^{1}$, M. Nadeem ${ }^{1}$, A. Majeed ${ }^{2}$ \\ and B. A. Rischkowsky ${ }^{3}$
}

\author{
${ }^{1}$ Department of Agronomy, PMAS-Arid Agriculture University Rawalpindi, Pakistan; \\ ${ }^{2}$ ICARDA Country Representative, NARC, Islamabad, Pakistan; ${ }^{3}$ International Center for \\ Agricultural Research in the Dry Areas, PO Box 5466, Aleppo, Syria
}

\begin{abstract}
Livestock in rainfed area of Pothwar often faces green fodder scarcity during winter months and thus has to survive on cereal residues of previous crops such as wheat straw, summer sorghum, corn stalk etc. which are not rich source of protein and digestible nutrients. The basic objective of this experiment is to produce more fodder for livestock production and food for community. The investigations were carried out to evaluate the yield and quality of oat (Avena sativa L.), barely (Hordeum vulgare) and wheat (Triticum aestivum) in pure stands as well as in mixture of 50:50 ratios with common vetch (Vicia sativa L.) under rainfed conditions of Pothowar to address the problem of nutritious green fodder for livestock in the region. From the result of this study, it is evident that oatvetch mixture performed better under rainfed conditions of Pothowar in terms of green and dry matter yield. By this mixture, 37.97 tons ha ${ }^{-1}$ green and 9.28 ton ha ${ }^{-1}$ dry matter yield were obtained which are $20 \%$ higher than the pure stand of oat respectively. Similarly, it was found that overall oat + vetch, mixture yielded $63 \%$ and $78 \%$ higher dry matter than barley + vetch and wheat-vetch mixtures, respectively. Cereal + vetch mixture also produced higher crude protein content than their respective pure stands. Oats-vetch, barley + vetch and wheat + vetch resulted in $11.31 \%, 7.04 \%$ and $5.80 \%$ higher crude protein contents than their cereal pure stands respectively. With the advancement of growth stage, green fodder yield increased progressively while reverse was observed for qualitative traits. Maximum green fodder yield was obtained at 50\% heading stage while maximum crude protein content was achieved at tillering stage in this study. On the basis of these field qualitative and quantitative investigations, cereal + vetch mixture is recommended for both obtaining higher tonnage and nutritious fodder under the rainfed conditions of Pothowar.
\end{abstract}

Keywords: Cereal + vetch mixture, fodder yield, quality, growth stages, rainfed conditions.

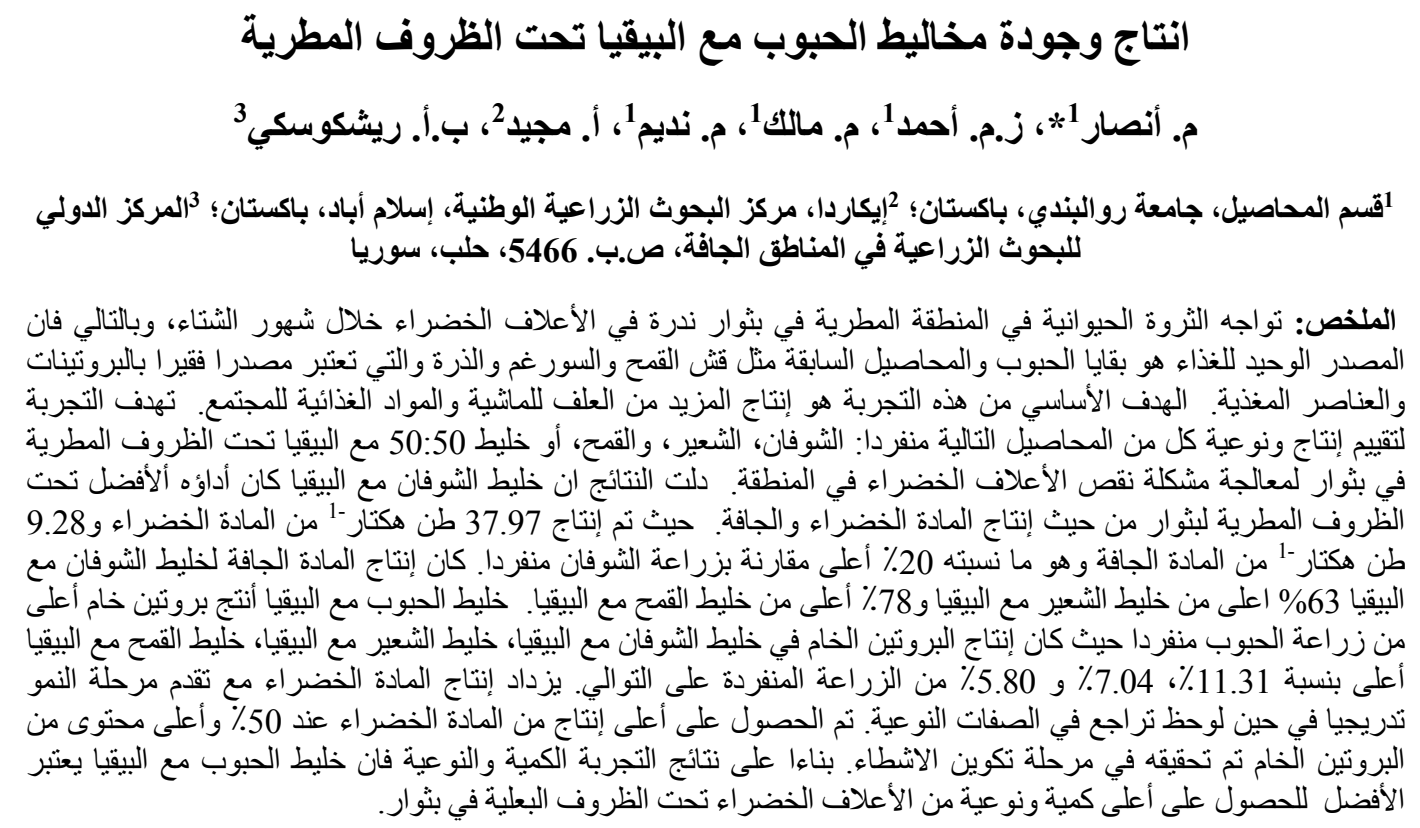

* Corresponding Author, Email: drmansar@yahoo.com 


\section{Introduction}

Livestock is an important sector of agriculture in Pakistan, which accounts for 49.6 percent of agricultural value addition and about 10.4 percent of the GDP. The role of livestock in the rural economy may be realized from the fact that 30-35 millions of rural population is engaged in livestock production with household holdings of 2-3 cattle/buffalo and 5-6 sheep/goat per family which help them to derive 30-40 percent of their income from it (Government of Pakistan, 2008).

Cereals like oat, barley and wheat are the important winter fodders grown under rainfed conditions of Pothowar for the sustenance of livestock. No doubt these crops are palatable, succulent and nutritious fodders with sufficient amount of carbohydrate, but are deficient in protein which is necessary for animal health and productivity. Literature also revealed that intake of fodder is low when fed as pure fodders either of legumes or cereals compared with their cereal legume mixtures. Oats form an excellent combination, when fed along with other cold season legume crops like berseem, Lucerne (alfalfa), senji (Indian clover), shaftal (Persian clover) and vetch (Vicia sativa) (Zaman et al., 2006). Barley too is winter hardy and potentially promising crop in the annual legume + cereal mixtures for forages and hay purposes (Yasar et al., 2003). The mixed cropping of vetch with oat, barely and wheat may affect the growth rate of the individual species in mixtures as well as the forage yield and quality (Lithourgidis et al., 2006). Oat, barely, wheat and triticale are added to provide a climbing frame for the legume and to increase the bulk of feed produce (Robert et al., 1989; Thompson et al., 1990; Canan and Orak, 2007). Findings of Jones and Singh (2000) showed that barely + vetch and barely + grass pea rotation yielded more dry matter and crude protein than barely-barely or barely- fallow rotation. Cereal species, grown with legume mixture components may affect yield and quality of forage produced by mixtures (Droushiotis, 1989; Papastylianou, 1990; and Caballero et al., 1995). Jensen (1996) reported the advantages of growing vetch and wheat together produced higher seed and protein yield than sole cereal while Caballero and Goicoechea (1986) reported that barley (Hordeum vulgare L.) is the most suitable cereal for fodder mixtures. Keeping in view the importance of cereal + vetch mixture for fodder purpose in Pothowar region, a study was undertaken to evaluate the fodder yield potential and quality of cereals and legume in mono as well as in mix culture at different crop growth stages.

\section{Materials and Methods Site}

An experiment was carried out at Koont Research Farm $\left(33^{\circ} \mathrm{N}\right.$ and $\left.42.72^{\circ} \mathrm{E}\right)$ of Pir Mehr Ali Shah Arid Agriculture University Rawalpindi during the winter season of 2007-08.

The experiment comprised of oat, barely and wheat crops which were sown in pure stands at recommended seed rate as well as in mixture with legume (vetch). In mixture, the seed of component crops was homogenized at 50:50 ratios before sowing. The varieties of oat, barely, wheat and vetch crop were $\mathrm{PD}_{2}-\mathrm{LV}_{65}$, Snober-96, Afaq and Languedock and were sown at the rate of $80,100,50$ and $45 \mathrm{~kg} \mathrm{ha}^{-1}$, respectively, with single row hand drill at a row spacing of $30 \mathrm{~cm}$ apart. A randomized complete block design was used with three replications and seven treatments. Nitrogen and phosphorus fertilizers were applied @ 80 and $57 \mathrm{~kg} \mathrm{ha}^{-1}$ and were incorporated to the soil before sowing. The plot size of $3 \times 6 \mathrm{~m}$ was used for each treatment separated from each other, by producing a buffer zone of $1 \mathrm{~m}$. Rainfall and temperature recorded are presented in Figure 1 during the crop growth period.

The plant samples were taken from randomly selected $1 \mathrm{~m}^{2}$ area of each plot at different growth stages. It is worth mentioning here that growth stages were 
reported with respect to cereal crops especially oats.

Data regarding plant height, leaf to stem ratio, green fodder yield, dry matter yield, protein and crude fiber contents were recorded. To determine the green and dry fodder yield, an area of $1 \mathrm{~m}^{2}$ was harvested from each plot and it was converted into ha ${ }^{-1}$. The dry fodder yield was calculated after drying a sample of $500 \mathrm{~g}$ fodder in an oven at $78{ }^{0} \mathrm{C}$ for 48 hours. The plant height measured by averaging the natural standing height of five plants per plot. The results were analyzed by using MSTAT statistical computer program (MSTAT, 1982). To test the significance of treatments, analysis of variance techniques and to compare the means least significance difference test at $5 \%$ probability level was employed (James et al., 1997).

\section{Results and Discussion Plant height}

The growth determinants of any crop are important contributors toward the final yield by assimilating the natural and applied resources. Plant height is an important component of green fodder yield and is presented in Table 1. Plant height recorded at different crop growth stages showed significant differences among all the treatments.

Table 1. Effect of cereal + vetch pure stands and their mixtures on average plant height $(\mathrm{cm})$ at different crop growth stages during Rabi 2007- 2008.

\begin{tabular}{llllll}
\hline $\begin{array}{l}\text { Growth } \\
\text { Stages }\end{array}$ & $\begin{array}{l}\text { Tillering } \\
\text { (45 DAS) }\end{array}$ & $\begin{array}{l}\text { Booting } \\
\text { (75 DAS) }\end{array}$ & $\begin{array}{l}\text { Ear-emergence } \\
(\mathbf{1 0 5} \text { DAS) }\end{array}$ & $\begin{array}{l}\text { 50\% Heading } \\
(\mathbf{1 3 5} \text { DAS) }\end{array}$ & Means \\
\hline Oat & $32.10 \mathrm{n}^{*}$ & $51.83 \mathrm{jkl}^{*}$ & $112.66 \mathrm{~cd}^{*}$ & $122.4 \mathrm{~b}^{*}$ & $79.75 \mathrm{~A}^{*}$ \\
Barely & $23.86 \mathrm{n}$ & $44.26 \mathrm{~lm}$ & $93.88 \mathrm{ghi}$ & $105.75 \mathrm{def}$ & $66.94 \mathrm{~B}$ \\
Wheat & $28.15 \mathrm{n}$ & $48.3 \mathrm{~b} \mathrm{klm}$ & $93.22 \mathrm{j}$ & $102.4 \mathrm{efg}$ & $68.03 \mathrm{~B}$ \\
Vetch & $14.81 \mathrm{o}$ & $26.08 \mathrm{n}$ & $59.15 \mathrm{j}$ & $85.33 \mathrm{i}$ & $46.30 \mathrm{C}$ \\
Oat + Vetch & $25.48 \mathrm{n}$ & $54.33 \mathrm{jh}$ & $117.33 \mathrm{bc}$ & $131.37 \mathrm{a}$ & $82.13 \mathrm{~A}$ \\
Barely + & $27.03 \mathrm{n}$ & $43.08 \mathrm{~m}$ & $102.44 \mathrm{efg}$ & $108.38 \mathrm{de}$ & $70.23 \mathrm{~B}$ \\
Vetch & & & & $110.62 \mathrm{cde}$ & $69.78 \mathrm{~B}$ \\
Wheat + & $25.73 \mathrm{n}$ & $45.43 \mathrm{~lm}$ & $97.33 \mathrm{fgh}$ & $109.46 \mathrm{~A}$ & \\
Vetch & $25.31 \mathrm{E}^{*}$ & $44.77 \mathrm{D}$ & $96.55 \mathrm{~B}$ &
\end{tabular}

*Any two means not sharing a letter common in a row or column differ significantly at $5 \%$ probability level.

In pure stand, maximum plant height $(79.75 \mathrm{~cm})$ was attained by oat crop followed by wheat $(68.03 \mathrm{~cm})$, barley $(66.94 \mathrm{~cm})$ and the lowest by vetch $(46.30$ $\mathrm{cm})$ which is an inherited character of the crops. In mixtures, maximum plant height $(82.13 \mathrm{~cm})$ was obtained by oat + vetch mixture followed by barley + vetch mixture $(70.23 \mathrm{~cm})$ and then wheat + vetch by attaining $69.78 \mathrm{~cm}$ height. From the results, it appeared that the height character in mixture stand is mainly influenced by pure stand of the respective cereal crops. The results showed that the oat + vetch, barely + vetch and wheat + vetch mixtures attained $2.98 \%, 4.91 \%$ and $2.57 \%$ more plant height than their respective cereal counter parts which could be the result of efficient utilization of natural resources and minimum competition among the plants of different species. These results differ with the findings of Turemen et al. (1990) and Canan and Orak (2007), who reported the 
highest plant height in pure stand. In our study, there is possibility that the vetch legume may have shared the nitrogen fixed from atmosphere with its cereal counter part. It has been reported by Intkhab and Ahmad (2008) that the direct benefits of nitrogen fixation in root nodules of leguminous plant contributed to soil fertility which were used by companion as well as subsequent crops. Agboola and Fayami (1972) reported an increase in maize grain yield over the control when mungbean was inter-planted with the maize. Similarly, Gebrehiwot et al. (1997) found higher $\mathrm{N}$ content in maize grain that was intercropped with vetch whereas lablab and clover showed no such effects. It appears that tropical forage legumes differ markedly in their ability to benefit associated cereals that have approximately the same growing period. The issue of transfer of $\mathrm{N}$ from legumes to cereals is of great importance and controversial. Two types of beneficial effects have generally been reported; higher nitrogen content and higher grain yield of the intercropped cereals in comparison with the cereal alone without any added nitrogen. Henzell and Vallis (1977) found that presence or absence of cereal as grass has no specific effect on the release of $\mathrm{N}$ from actively growing roots; while Eaglesham (1980) and Reynolds (1982) have reported higher $\mathrm{N}$ content and uptake in mixtures compared to sole crop system.

\section{Leaf stem ratio}

Leaf stem ratio represents the leaf weight divided by stem weight. In pure stand, mean maximum leaf stem ratio was recorded in oat (1.08) followed by barley (0.76), wheat (0.68) and the lowest by vetch $(0.48)$. From data, it appears that leaf stem ratio in all the crops decreased with the advancement of crop growth stage. In mixtures, maximum leaf stem ratio was noted in oat + vetch $(0.85)$ followed by barley + vetch $(0.73)$ and the lowest in wheat + vetch (0.63) mixture (Table 2). The higher leaf stem ratio of oat + vetch mixture was probably the result of increased leaf area weight of the oat crop.

Table 2. Effect of cereal + vetch pure stands and their mixtures on average leaf stem ratio recorded at different crop growth stages during Rabi 2007- 2008.

\begin{tabular}{llllll}
\hline $\begin{array}{l}\text { Growth } \\
\text { stages }\end{array}$ & $\begin{array}{l}\text { Tillering } \\
\text { (45 DAS) }\end{array}$ & $\begin{array}{l}\text { Booting } \\
\text { (75 DAS) }\end{array}$ & $\begin{array}{l}\text { Ear-emergence } \\
\text { (105 DAS) }\end{array}$ & $\begin{array}{l}\text { 50\% Heading } \\
\text { (135 DAS) }\end{array}$ & Means \\
\hline Barely & $1.5 \mathrm{~b}$ & $0.9 \mathrm{ef}$ & $0.3 \mathrm{j}$ & $0.26 \mathrm{j}$ & $0.76 \mathrm{BC}$ \\
Wheat & $1.2 \mathrm{cde}$ & $0.8 \mathrm{fg}$ & $0.4 \mathrm{ij}$ & $0.33 \mathrm{j}$ & $0.68 \mathrm{C}$ \\
Vetch & $0.7 \mathrm{fgh}$ & $0.5 \mathrm{hij}$ & $0.5 \mathrm{hij}$ & $0.33 \mathrm{j}$ & $0.48 \mathrm{D}$ \\
Oat + Vetch & $1.4 \mathrm{bcd}$ & $1.2 \mathrm{de}$ & $0.4 \mathrm{hij}$ & $0.38 \mathrm{ij}$ & $0.85 \mathrm{~B}$ \\
Barely + Vetch & $1.5 \mathrm{bc}$ & $0.8 \mathrm{f}$ & $0.3 \mathrm{j}$ & $0.26 \mathrm{j}$ & $0.73 \mathrm{BC}$ \\
Wheat + Vetch & $1.2 \mathrm{de}$ & $0.8 \mathrm{f}$ & $0.3 \mathrm{j}$ & $0.25 \mathrm{j}$ & $0.63 \mathrm{CD}$ \\
\hline Means & $1.36 \mathrm{~A}^{*}$ & $0.90 \mathrm{~B}$ & $0.39 \mathrm{C}$ & $0.34 \mathrm{C}$ & \\
\hline
\end{tabular}

$*$ Any two means not sharing a letter common in a row or column differ significantly at $5 \%$ probability level.

\section{Green fodder yield $\left(\mathrm{t} \mathrm{ha}^{-1}\right)$}

Data regarding different cereallegume mixtures and pure stands of individual crop at different growth stages are presented in Table 3. There are significant differences among the green fodder yield at different crop growth stages. 
Table 3. Effect of cereal + vetch pure stands and their mixtures on green fodder yield $\left(\mathrm{t} \mathrm{ha}^{-1}\right)$ recorded at different crop growth stages during Rabi 2007- 2008.

\begin{tabular}{llllll}
\hline $\begin{array}{l}\text { Growth } \\
\text { Stages }\end{array}$ & $\begin{array}{l}\text { Tillering } \\
(45 \mathrm{DAS})\end{array}$ & $\begin{array}{l}\text { Booting } \\
(75 \mathrm{DAS})\end{array}$ & $\begin{array}{l}\text { Ear-emergence } \\
(105 \mathrm{DAS})\end{array}$ & $\begin{array}{l}\mathbf{5 0 \%} \text { Heading } \\
(135 \mathrm{DAS})\end{array}$ & Means \\
\hline Oat & $5.73 \mathrm{klm}^{*}$ & $12.32 \mathrm{jk}{ }^{*}$ & $49.00 \mathrm{c}^{*}$ & $59.26 \mathrm{c}^{*}$ & $31.58 \mathrm{~B}^{*}$ \\
Barely & $5.50 \mathrm{klm}$ & $11.54 \mathrm{jkl}$ & $35.66 \mathrm{efg}$ & $41.45 \mathrm{cde}$ & $23.54 \mathrm{CD}$ \\
Wheat & $6.15 \mathrm{jklm}$ & $7.85 \mathrm{jklm}$ & $31.33 \mathrm{gh}$ & $34.7 \mathrm{efg}$ & $20.01 \mathrm{DE}$ \\
Vetch & $2.29 \mathrm{~m}$ & $5.12 \mathrm{klm}$ & $22.33 \mathrm{i}$ & $25.3 \mathrm{hi}$ & $13.76 \mathrm{~F}$ \\
Oat + Vetch & $4.11 \mathrm{~lm}$ & $11.49 \mathrm{jkl}$ & $65.13 \mathrm{ab}$ & $71.15 \mathrm{a}$ & $37.97 \mathrm{~A}$ \\
Barely + Vetch & $6.39 \mathrm{jklm}$ & $13.47 \mathrm{j}$ & $33.33 \mathrm{fg}$ & $44.32 \mathrm{~cd}$ & $24.38 \mathrm{C}$ \\
Wheat + Vetch & $4.57 \mathrm{~lm}$ & $7.38 \mathrm{jklm}$ & $22.33 \mathrm{i}$ & $39.38 \mathrm{def}$ & $18.42 \mathrm{~A}$ \\
\hline Means & $4.96 \mathrm{D}$ & $9.88 \mathrm{C}$ & $37.02 \mathrm{~B}$ & $45.08 \mathrm{~A}$ & \\
\hline
\end{tabular}

*Any two means not sharing a letter common in a row or column differ significantly at $5 \%$ probability level.

In pure stand, there were no significant differences among the treatment means at early growth stages but later in the season, oat crop produced the highest green fodder yield than all the other crops. The results of these investigations are similar with those of Canan and Orak (2007), who investigated oat + vetch mixtures in different ratio and recorded the highest herbage yield in oat and the lowest in vetch in pure stands. The overall green fodder yield recorded from pure stands of crops at different crop growth stages showed ranking of oat, barley, wheat and vetch in descending order. In general, growth rate in all the crops remained slower during December and January while it increased with faster rate from February to April (Figure 1). It was most probably due to increase of temperature and availability of moisture with the occurrence of rainfall during February.

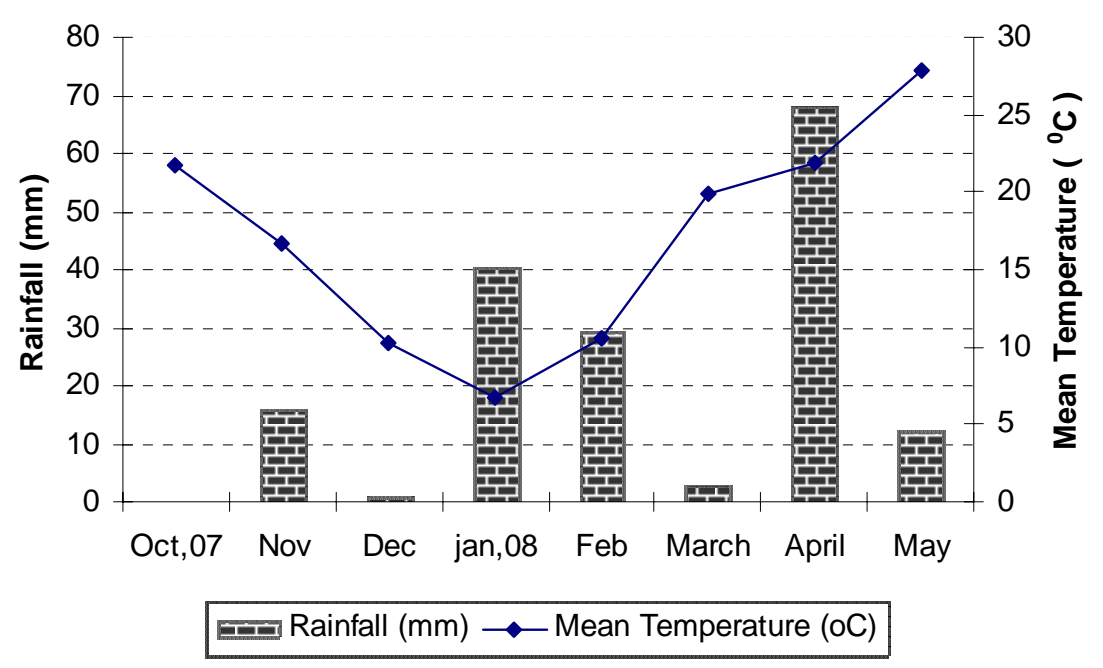

Figure 1. Rainfall and temperature recorded during the crop growth period.

The highest green fodder yield (about 38 $\mathrm{t} \mathrm{ha}^{-1}$ ) was obtained in oat + vetch mixture followed by barley +vetch and the lowest in wheat + vetch mixture. This might be due to the result of cereals being able to provide support for the climbing vetches thus improved the light interception and vetch in turn might shared the nitrogen fixed from the atmosphere with the cereal counter part and resultantly enhanced both yield and nutrition. 
The incorporation of legume with cereal could be of paramount importance to the nutritive value of the forage mixture and subsequent soil health. These results are in line with the findings of Canan and Orak (2007) who reported that mixtures were more productive than pure vetch sowing. He also reported that the highest herbage yield was obtained from mixture of vetch and oats while the lowest herbage yield from pure stands of vetch. The pure oat stand herbage yield remained in between the mixtures and pure stand of vetch. In early growth, barley + vetch mixture produced higher green fodder yield followed by oat + vetch and wheat + vetch mixture. The higher green fodder yield in early growth stages may attributed to greater number of tillers plant ${ }^{-1}$.

\section{Dry matter yield $\left(\mathrm{t} \mathrm{ha}^{-1}\right)$}

The dry matter yield recorded at different growth stages of the crops mixtures and pure stands is presented in Table 4. From the data it appeared that dry matter yield trend is similar to green fodder yield. In pure stands, the highest dry matter yield was obtained by the oat crop followed by barley, wheat and the lowest in vetch. Ahmad et al. (2008) found that early maturing oats variety, S-2000 consistently performed better over a period of four years than rest of the cultivars tested. In mixtures of cereal + legume, the highest dry matter yield was obtained from oat + vetch mixture in all the successive harvests which followed by barley + vetch and wheat + vetch mixtures. Similar, results were reported by Tuna and Orak (2007) who found the highest dry matter yield in oat vetch mixture and the lowest in vetch crop. He further mentioned that as the seed rate of vetch in mixture increased, the herbage and dry matter yield decreased. The oat-vetch mixture gave higher dry matter yield as compared to other mixtures. Anwar et al. (2010) tested non traditional legume mixtures with oats and found that oats + vetch yielded better than oat + senji and oats + medic mixtures. The mixtures gave higher yields than the pure sowings, however, the best cutting stage is shown in the Figure 4 which comes almost hundred days after sowing. Beyond this stage, the grower has to scarify either for the protein or for fodder yield. The findings of this study are similar to the findings of Al-Masri (1998) and Rauber et al. (2000). Assefa and Ledin (2001) also reported that DM forage yield of pure vetch; pure oat and mixture were 4.3, 7.6 and $7.3 \mathrm{t}$ $\mathrm{ha}^{-1}$ respectively.

Table 4. Effect of cereal + vetch pure stands and their mixtures on dry matter yield $\left(\mathrm{t} \mathrm{ha}^{-1}\right)$ recorded at different crop growth stages during Rabi 2007- 2008.

\begin{tabular}{llllll}
\hline $\begin{array}{l}\text { Growth } \\
\text { Stages }\end{array}$ & $\begin{array}{l}\text { Tillering } \\
\text { (45 DAS) }\end{array}$ & $\begin{array}{l}\text { Booting } \\
(75 \mathrm{DAS})\end{array}$ & $\begin{array}{l}\text { Ear-emergence } \\
(105 \mathrm{DAS})\end{array}$ & $\begin{array}{l}\mathbf{5 0 \%} \text { Heading } \\
(135 \mathrm{DAS})\end{array}$ & Means \\
\hline Barely & $0.94 \mathrm{lmn}$ & $1.66 \mathrm{~lm}$ & $8.44 \mathrm{ghi}$ & $9.64 \mathrm{ef}$ & $5.17 \mathrm{D}$ \\
Wheat & $0.87 \mathrm{lmn}$ & $1.46 \mathrm{~lm}$ & $7.73 \mathrm{ij}$ & $8.74 \mathrm{gh}$ & $4.70 \mathrm{E}$ \\
Vetch & $0.55 \mathrm{n}$ & $0.83 \mathrm{mn}$ & $7.11 \mathrm{j}$ & $7.71 \mathrm{ij}$ & $4.04 \mathrm{~F}$ \\
Oat + Vetch & $1.23 \mathrm{lmn}$ & $3.31 \mathrm{k}$ & $15.18 \mathrm{~b}$ & $17.42 \mathrm{a}$ & $9.28 \mathrm{~A}$ \\
Barely + Vetch & $0.96 \mathrm{lmn}$ & $1.71 \mathrm{l}$ & $9.23 \mathrm{fg}$ & $10.87 \mathrm{~d}$ & $5.69 \mathrm{C}$ \\
Wheat + Vetch & $0.91 \mathrm{lmn}$ & $1.57 \mathrm{~lm}$ & $8.12 \mathrm{hi}$ & $10.31 \mathrm{de}$ & $5.22 \mathrm{D}$ \\
\hline Means & $0.92 \mathrm{D}^{*}$ & $1.76 \mathrm{C}$ & $9.88 \mathrm{~B}$ & $11.42 \mathrm{~A}$ & \\
\hline
\end{tabular}

${ }^{*}$ Any two means not sharing a letter common in a row or column differ significantly at $5 \%$ probability level.

\section{Crude fiber $\left(\mathrm{g} \mathrm{kg}^{-1}\right)$}

Crude fiber is one of the most important parameters for quality evaluation. Data regarding crude fiber content during the year
2007-08 showed that in pure stand treatments, maximum crude fiber content $\left(280.0 \mathrm{~g} \mathrm{~kg}^{-1}\right)$ was obtained from wheat crop followed by barley and oats and the lowest by vetch 
during winter season of 2007-08. The results showed that oat + vetch, barely + vetch and wheat + vetch mixture crops produced higher crude fiber content than their respective cereal counter parts which could be the result of efficient utilization of moisture and nutrients. The results showed that oat + vetch, barley + vetch and wheat + vetch mixture crops attained $13.32 \%, 13.15 \%$ and $2.78 \%$ higher crude fiber content than their respective pure stands (Figure 2). Data recorded at different growth stages also showed significant differences from each other. With the advancement of growth stage, crude fiber content increased progressively (Table 5). There was highly positive corelationship $\left(\mathrm{R}^{2}=0.96\right)$ between plant height and crude fiber content as the fiber content increased with the increase of plant height. The maximum crude fiber content in cereals was recorded at $50 \%$ heading and the lowest at tillering stage. Similar results were reported by Alzueta et al. (2001).

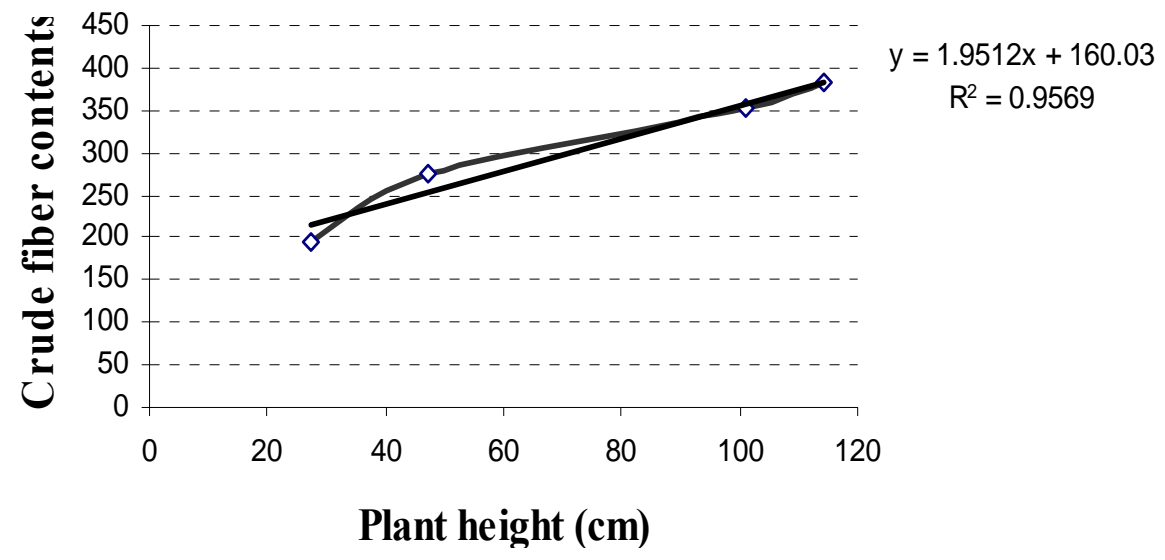

Figure 2. Relationship between plant height and crude fiber $\left(\mathrm{g} \mathrm{kg}^{-1}\right)$ at different growth stages during the year 2008-09.

Table 5. Effect of cereal + vetch pure stands and their mixtures on crude fiber content $\left(\mathrm{g} \mathrm{kg}^{-1}\right)$ recorded at different crop growth stages during Rabi 2007- 2008.

\begin{tabular}{|c|c|c|c|c|c|}
\hline \multirow[b]{2}{*}{ Treatments } & \multicolumn{4}{|c|}{ Growth Stages } & \multirow[b]{2}{*}{ Means } \\
\hline & $\begin{array}{l}\text { Tillering } \\
\text { (45 DAS) } \\
\end{array}$ & $\begin{array}{l}\text { Booting } \\
\text { (75 DAS) } \\
\end{array}$ & $\begin{array}{l}\text { Ear-emergence } \\
\text { (105 DAS) }\end{array}$ & $\begin{array}{l}\text { 50\% Heading } \\
\text { (135 DAS) }\end{array}$ & \\
\hline Oat & $150.00 \mathrm{q}^{*}$ & $220.00 \mathrm{n}^{*}$ & $340.00 \mathrm{f}^{*}$ & $380.00 \mathrm{c}^{*}$ & $272.5 \mathrm{E}^{*}$ \\
\hline Barely & $145.00 \mathrm{q}$ & $250.00 \mathrm{~m}$ & $355.00 \mathrm{e}$ & $375.00 \mathrm{~cd}$ & $281.3 \mathrm{D}$ \\
\hline Wheat & $175.00 \mathrm{p}$ & $280.00 \mathrm{jk}$ & $320.00 \mathrm{~h}$ & $345.00 \mathrm{f}$ & $280.0 \mathrm{D}$ \\
\hline Vetch & $210.00 \mathrm{o}$ & $275.00 \mathrm{kl}$ & $295.00 \mathrm{i}$ & $315.00 \mathrm{~h}$ & $273.7 \mathrm{E}$ \\
\hline Oat + Vetch & $210.00 \mathrm{o}$ & 270.001 & $355.00 \mathrm{e}$ & $400.00 \mathrm{~b}$ & $308.8 \mathrm{~B}$ \\
\hline Barely + Vetch & $173.00 \mathrm{p}$ & $320.00 \mathrm{~h}$ & $370.00 \mathrm{~d}$ & $414.18 \mathrm{a}$ & $319.3 \mathrm{~A}$ \\
\hline Wheat + Vetch & $178.00 \mathrm{p}$ & $285.00 \mathrm{j}$ & $330.00 \mathrm{~g}$ & $358.00 \mathrm{e}$ & $287.8 \mathrm{C}$ \\
\hline Means & $177.3 \mathrm{D}^{*}$ & $271.4 \mathrm{C}$ & $337.9 \mathrm{~B}$ & $369.6 \mathrm{~A}$ & \\
\hline
\end{tabular}

${ }^{*}$ Any two means not sharing a letter common in a row or column differ significantly at $5 \%$ probability level.

\section{Crude protein $\left(\mathrm{g} \mathrm{kg}^{-1}\right)$}

Crude protein is one of the most important criteria for fodder quality evaluation. Data regarding crude protein content recorded during 2007-08 were presented in Table 6 . In pure stand treatments, maximum crude protein content (47.72 $\left.\mathrm{g} \mathrm{kg}^{-1}\right)$ was obtained in 
vetch crop followed by wheat $(41.55 \mathrm{~g}$ $\left.\mathrm{kg}^{-1}\right)$, barley $\left(41.19 \mathrm{~g} \mathrm{~kg}^{-1}\right)$ and the lowest in oats $\left(39.96 \mathrm{~g} \mathrm{~kg}^{-1}\right)$. The results showed that oat + vetch, barley + vetch and wheat
+ vetch mixture crops produced $1.43 \%$, $7.04 \%$ and $5.80 \%$ respectively higher crude protein content than their cereal pure stands.

Table 6. Effect of cereal + vetch pure stands and their mixtures on crude protein content $\left(\mathrm{g} \mathrm{kg}^{-1}\right)$ recorded at different crop growth stages during Rabi 2007- 2008.

\begin{tabular}{llllll}
\hline \multirow{2}{*}{ Treatments } & \multicolumn{6}{l}{ Growth Stages } & & \\
\cline { 2 - 6 } & $\begin{array}{l}\text { Tillering } \\
\text { (45 DAS) }\end{array}$ & $\begin{array}{l}\text { Booting } \\
\text { (75 DAS) }\end{array}$ & $\begin{array}{l}\text { Ear-emergence } \\
\text { (105 DAS) }\end{array}$ & $\begin{array}{l}\text { 50\% Heading } \\
\text { (135 DAS) }\end{array}$ & Means \\
\hline Oat & $53.70 \mathrm{e}^{*}$ & $38.46 \mathrm{ij}^{*}$ & $28.38 \mathrm{~lm}^{*}$ & $25.11 \mathrm{mn}^{*}$ & $39.96 \mathrm{D}^{*}$ \\
Barely & $57.99 \mathrm{cde}$ & $41.39 \mathrm{ghi}$ & $36.98 \mathrm{ijk}$ & $28.39 \mathrm{~lm}$ & $41.19 \mathrm{C}$ \\
Wheat & $65.30 \mathrm{ab}$ & $44.46 \mathrm{fgh}$ & $35.06 \mathrm{jk}$ & $21.38 \mathrm{n}$ & $41.55 \mathrm{BC}$ \\
Vetch & $54.37 \mathrm{de}$ & $66.46 \mathrm{ab}$ & $40.54 \mathrm{hi}$ & $29.50 \mathrm{~lm}$ & $47.72 \mathrm{~A}$ \\
Oat + Vetch & $59.63 \mathrm{~cd}$ & $44.55 \mathrm{fgh}$ & $31.80 \mathrm{kl}$ & $26.12 \mathrm{mn}$ & $40.53 \mathrm{C}$ \\
Barely + Vetch & $61.97 \mathrm{bc}$ & $46.37 \mathrm{fg}$ & $38.52 \mathrm{ij}$ & $29.50 \mathrm{~lm}$ & $44.09 \mathrm{~B}$ \\
Wheat + Vetch & $68.80 \mathrm{a}$ & $48.20 \mathrm{f}$ & $36.62 \mathrm{ijk}$ & $22.22 \mathrm{n}$ & $43.96 \mathrm{~B}$ \\
\hline Means & $60.25 \mathrm{~A}^{*}$ & $41.13 \mathrm{~B}$ & $35.42 \mathrm{C}$ & $26.03 \mathrm{D}$ & \\
\hline Any twO ma
\end{tabular}

$*$ Any two means not sharing a letter common in a row or column differ significantly at $5 \%$ probability level.

Similarly, Gebrehiwot et al. (1997) found higher $\mathrm{N}$ content in maize grain that was intercropped with vetch whereas lablab and clover showed no such effect. In pure stands mean maximum crude protein content was obtained in wheat at tillering stage and minimum crude protein contents was attained in oat at $50 \%$ heading stage while in mixture treatments mean maximum crude protein content was produced by wheat + vetch mixture at tillering stage and minimum crude protein content was produced in wheat + vetch mixture at $50 \%$ heading stage. A highly negative correlation $\left(\mathrm{R}^{2}=0.84\right)$ between plant height and protein content was observed as the protein content decreased with the increase of plant height (Figure $3,4)$.

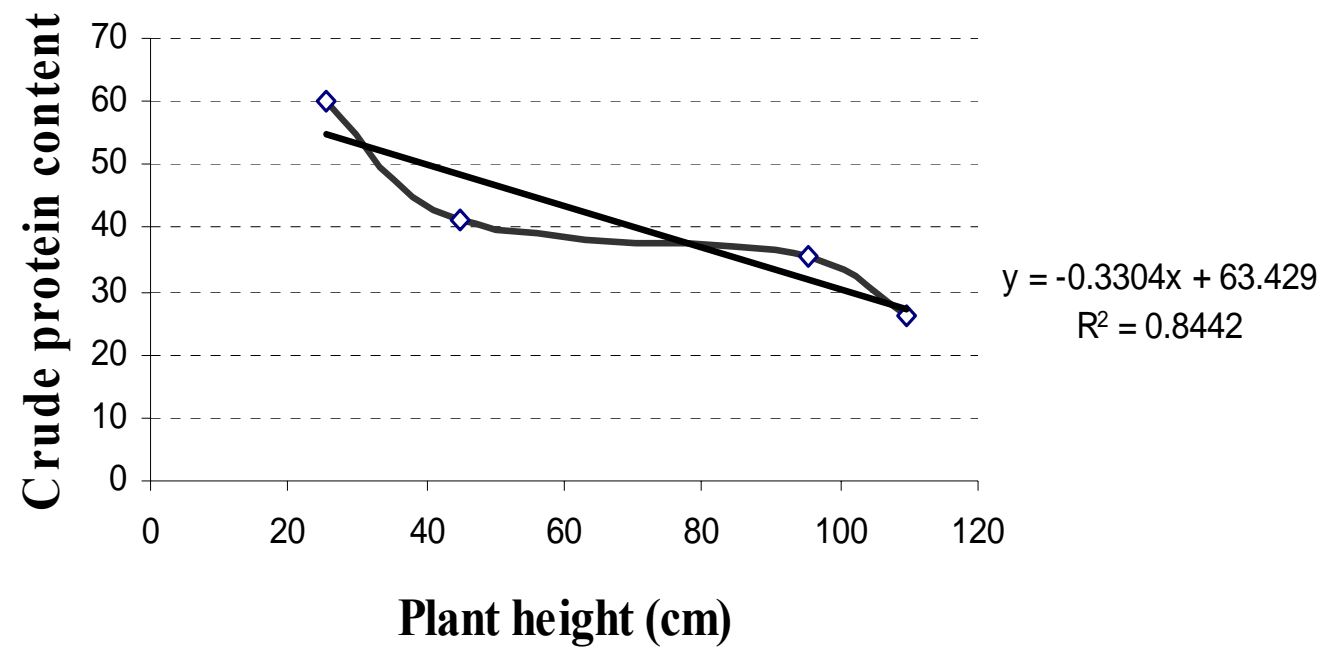

Figure 3. Relationship between plant height and crude protein $\left(\mathrm{g} \mathrm{kg}^{-1}\right)$ at different growth stages during the year 2007-08. 
Emir. J. Food Agric. 2010. 22 (1): 25-36

http://ffa.uaeu.ac.ae/ejfa.shtml

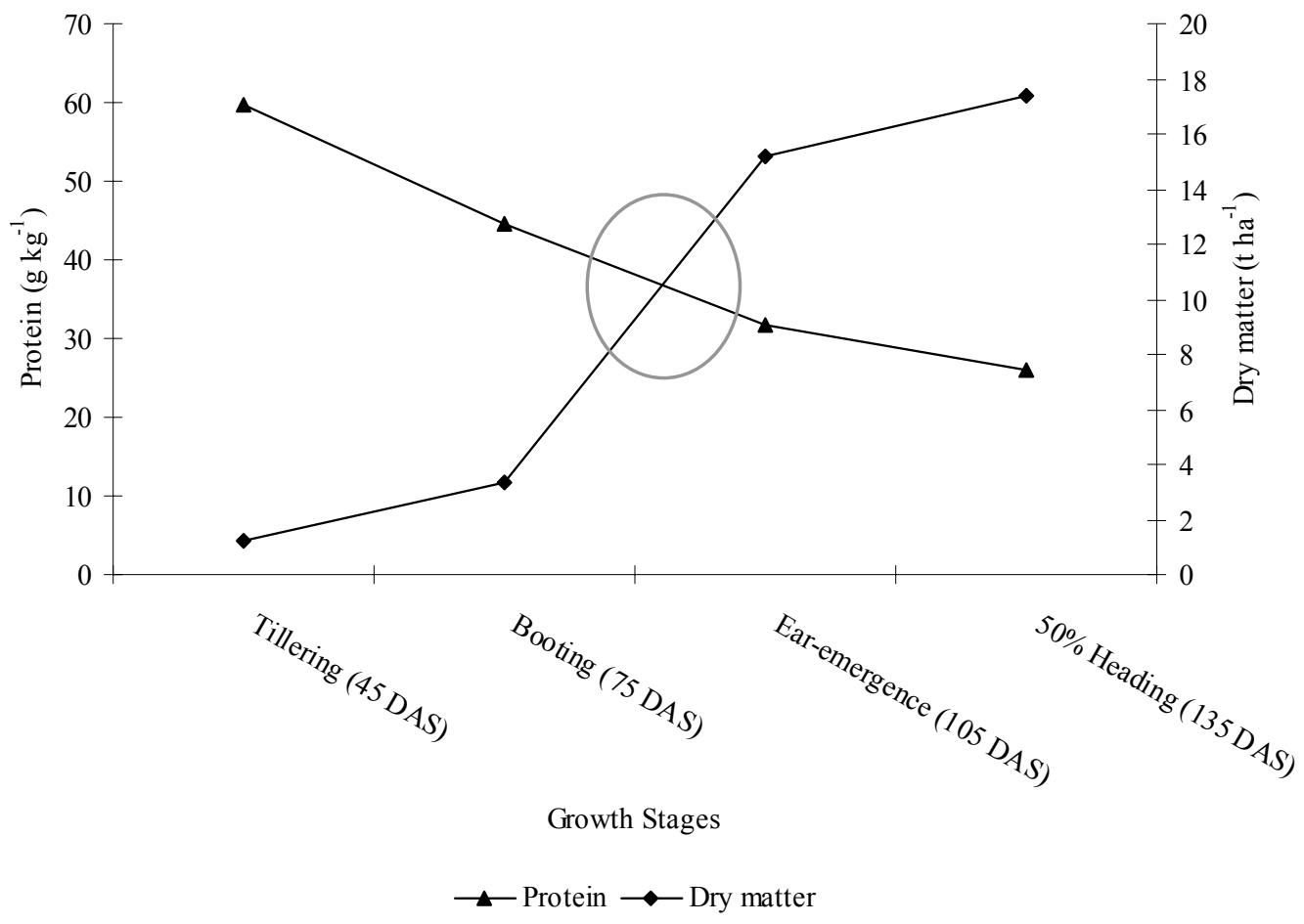

Figure 4. Oat + vetch dry matter yield and protein content at different growth stages showing the ideal cutting stage during the year 2007-08.

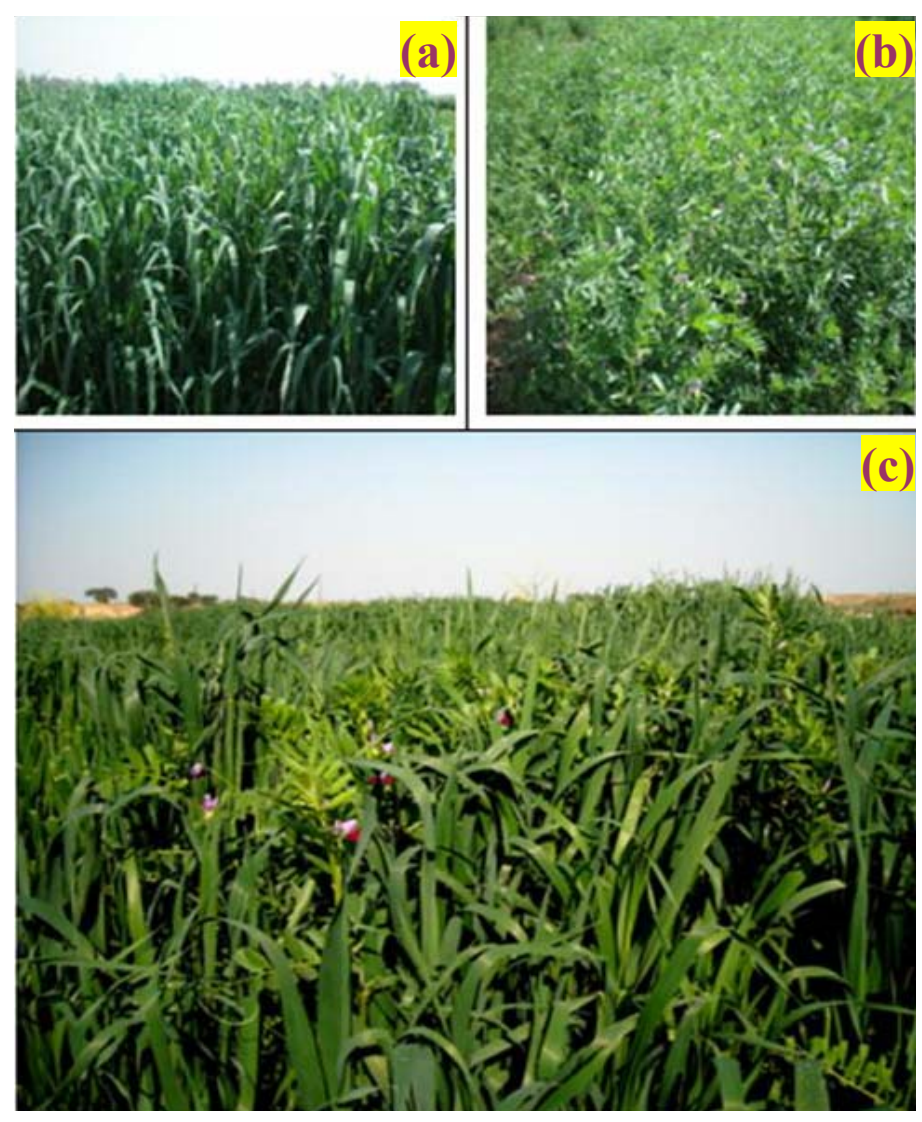

Figure 5. Field view of (a) Pure stand of oat crop (b) Pure stand of vetch crop and (c) Oats + Vetch mixture. 
According to the results of research study, mixtures produced higher tonnage and nutritious fodder than their respective cereal pure stands. The highest green fodder and dry matter yield was obtained from oat + vetch mixture compared to barley + vetch and wheat + vetch mixtures under rainfed conditions of Pothowar (Figure 5). Fodder yield increased progressively with the advancement of the growth stage which was maximum at $50 \%$ heading while the fodder quality decreased with the advancement of the growth stage and was minimum at $50 \%$ heading stage. Further more, it is also added that vetch has little regrowth ability therefore its harvesting is discouraged at early growth stage.

\section{Acknowledgement}

The study has been made possible by the financial support from IFAD Technical Assistance Grant (TAG): ICARDA-816 in the form of project "Community Action in Integrated and Market- Oriented Feed Livestock Production in Central and South Asia" being implemented by ICARDA in Pakistan

\section{References}

Agboola A. A. and A. A. Fayami. 1972. Fixation and excretion of nitrogen by tropical legumes. Agron. J. 64: 409412.

Ahmad, G., M. Ansar, S. Kaleem, G. Nabi and M. Hussain. 2008. Performance of early maturing oats cultivars for yield and quality. J. Agri. Res. 46(2): 341-346.

Al-Masri, M. R. 1998. Yield and nutritive of vetch - barely forage under different harvesting regimens. Trop. Grasslands 32:201-206.

Alzueta, C., R. Caballero, A. Rebole, J. Trevino and A. Gill. 2001. Crude protein fraction in common vetch fresh forage during pod filling. J. Animal Sci. 79:2449-2455.

Anwar, A., M. Ansar, M. Nadeem, G. Ahmad, S. Khan and A. Hussain. 2010. Performance of non traditional winter legumes with oat for forage yield and soil health under rainfed conditions. J. Agri. Res. 48(1) (in press).

Assefa, G. and I. Ledin. 2001. Effect of variety, soil type, and fertilizer on the establishment, growth, forage yield, quality and voluntary intake by cattle of oats and vetches cultivated in pure stands and mixtures. Anim. Feed. Sci. Tech. 92:95-111.

Caballero, R. and E. L. Goicoechea. 1986. Utilization of winter cereals as companion crops for common vetch and hairy vetch. Proceedings of the 11th General Meeting of the European Grass. Fed. 379-384.

Caballero, R., E. L. Goicoechea and P. J. Hernaiz. 1995. Forage yield and quality of common vetch and oat sown at varying seeding ratios and seeding rates of common vetch. Field Crops Res. 41:135-140.

Canan, T. and A, Orak. 2007. The role of intercropping on yield potential of common vetch (Vicia sativa L.) /oat (Avena sativa L.) cultivated in pure stand and mixtures. J. Agric. Biol. Sci. 2:14-19.

Droushiotis, D. N. 1989. Mixtures of annual legumes and small-grained cereals for forage production under low rainfall. J. Agric. Sci. 113:249253.

Eaglesham, A. R. J. 1980. Fertilizer use efficiency studies in intercropping systems using N-15. In: Nuclear techniques in the development of 
management practices for multiple cropping systems. IAEA, Vienna. pp. 15-27.

Gebrehiwot, L., R. L. McGraw and G. Assefa. 1997. Dry matter yield and forage quality of perennial grasses interseeded with annual legumes in the tropical highlands of Thiopia. Tropic. Agric. 74:173-179.

Government of Pakistan. 2008. Economic Survey of Pakistan 2007-08, Ministry of Finance, Govt. of Pakistan, Islamabad. pp. 15.

Henzell, E. F. and I. Vallis. 1977. Transfer of nitrogen between legumes and other crops. In: Ayanaba, A. and P. J. Dart (eds). Biological nitrogen fixation in farming system of the tropics. John Wiley and Sons, New York, pp. 7388.

Intkhab, H. W. and R. Ahmad. 2008. Intercropping barely with legumes. Dawn, Apr. 2008.

James T. M., H. D. Frank and S. Terry. 1997. Statistics. $7^{\text {th }}$ Ed. Prentice-Hall, International Inc. Co. New Jersy. pp. 429-443.

Jensen, E. S. 1996. Grain yield, symbiotic $\mathrm{N}_{2}$ fixation and interspecific for inorganic $\mathrm{N}$ in pea-barley intercrops. J. Plant Soil. 182:25-38.

Jones, M. J. and M. Singh. 2000. Long term yield patterns in barley -based cropping systems in northern Syria. J. Agri. Sci. 135:251-259.

Lithourgidis, A. S., I. B. Vasilakoglou, K. V. Dhima, C. A. Dordas and M. D. Yiakoulaki. 2006. Forage yield and quality of common vetch mixtures with oat and triticale in two seeding ratios. Field Crops Res. 99:106-113.
MSTAT, 1982. MSTAT Version 3, 0/EM. Packet program Department of Crop Science, Michigan State University, USA.

Papastylianou, I. 1990. Response of pure stands and mixtures of cereals and legumes to nitrogen fertilization and residual effects on subsequent barley. J. Agri. Sci. 115:15-22.

Rauber, R., Schmidtke, K. and H. KimpelFreund. 2000. Konkurrenz undtragsvorteile in gemengen aus erbsen (Pisum sativum L.) und hafer (Avena sativa L.). J. Agri. Sci. 185:33-77.

Reynolds, S. G. 1982. Contribution to yield, nitrogen fixation and transfer by local and exotic legumes in tropical grass-legume mixtures in Western Somoa. Trop. Grassl. Sci. 16(2):7 6-82.

Robert, C. A., K. I. Moore and K. D. Johoson. 1989. Forage quality and yield of wheat-vetch at different stages of maturity and vetch seeding rates. Agri. J. 81: 57-60.

Thompson, E. F., S. Rihawi and N. Nersoyan. 1990. Nutritive value and yields of some forage legumes and barley harvested as immature herbage, hay and straw in North-West Syria. Exp. Agri. 26:49-56.

Tuna, C. and A. Orak. 2007. The role of intercropping on yield potential of common vetch (Vicia sativa L.) / oat (Avena sativa L.) cultivated in pure stand and mixtures. J. Agric. Biol. Sci. 2:14-19.

Turemen, T., T. Saglamtimur, V. Tansi and H. Baytekin. 1990. Performance of annual ryegrass and common vetch in association under different ratio. J. Fac. Agr. 5:69-78. 
M. Ansar et al.

Yasar, K. and U. Buyukbure. 2003. Effect of seed rate on forage production, seed yield and hay quality of annual legumes-barley mixtures. Turk. J. Agri. 27:169-174.
Zaman, Q., M. N. Hussain, A. Aziz and K. Hayat. 2006. Performance of high yielding oat varieties under agroecological conditions of D.I. khan. J. Agric. Res. 44:29-35. 